American Journal of Pharmaceutical Education 2020; 84 (9) Article 8062.

\title{
COMMENTARY
}

\section{On Being Present With Learners and the Deeper Lessons From Acting}

\author{
Daniel R. Malcom, PharmD \\ Sullivan University College of Pharmacy and Health Sciences, Louisville, Kentucky \\ Associate Editor, American Journal of Pharmaceutical Education, Arlington, Virginia \\ Submitted March 16, 2020; accepted March 26, 2020; published September 2020.
}

Keywords: teaching, acting, faculty development, education

Recently, while preparing materials for an upcoming course, I was reminded of how much my own style and approach to the classroom has changed in the 10 years since I began as a faculty member. Fresh out of residency training and new in my teaching role, the sense of excitement I felt in sharing my clinical knowledge with new learners often overpowered my memory of being a novice learner and feeling overwhelmed and frightened of all that I did not know. As a result, during my first years of teaching, my lectures were packed full of information, with less concern given to how I engaged with students and residents during the learning process itself. While teaching, I also found myself lost in worrying about how the class was perceiving me. I fixated on any errors I made in preparing or delivering the materials that I could address in future course offerings. These distractions were in addition to the normal intersection of priorities related to starting a new faculty position, which included responsibilities at my practice site, service to various organizations, and experiential teaching.

Like many faculty members, over time I gained maturity and experience (as well as received keenly accurate and insightful student evaluations of my teaching) and became increasingly more learner-centered in my approach to teaching. I began to regularly ask myself, "What did I know at this stage in my own learning process?" and "How did I feel before and after learning this information for the first time?" when deciding which information to include in my teaching and how to organize it. Because of this approach, the same sense of excitement I initially felt about teaching is still present, but it is filtered retrospectively as I intentionally place myself psychologically and cognitively back in the role of the novice learner. The balance of intersecting priorities has also abated somewhat over time as knowledge gained and relationships developed have helped me understand the

Corresponding Author: Daniel R. Malcom, Sullivan

University College of Pharmacy and Health Sciences, 2100

Gardiner Ln., Louisville, KY 40205. Tel: 502-413-8969.

Email: dmalcom@sullivan.edu team-based approach to all aspects of the faculty member role. While the changes I implemented were helpful, I found that during class I was still thinking ahead about ways to improve the material for subsequent iterations rather than focusing on the "in-the-moment" experience of the learners in front of me. I found that the goal of iterative improvement over time was preventing me from being mentally and cognitively present with the learners during the process. Stated another way, thinking about the future was blocking my ability to live in the now.

This concept of being "in the moment" with learners is similar to aspects of the acting profession. Much has been written about teaching as its own type of performance art, with discussion of applying the "TED Talk" model, which focuses on storytelling and communication, to instructional activities. ${ }^{1-4}$ Less has been written, however, on the deeper and more nuanced lessons acting may provide for how we view learning as well as learners themselves that can help us improve our craft as teachers. ${ }^{5-7}$ Importantly, for this discussion I am not referring to the nature of scripted performance (vs improvisational) or any semblance of presenting fictional material for learners, but rather on how actors are trained and how aspects of that training can apply to education.

Actors are taught to embody their characters and feel their emotions genuinely and deeply so that the performance is perceived by the audience as authentic. ${ }^{7,8}$ They are taught to be present with their thoughts and feelings in every moment of the performance to help carry forward this authenticity and be as true as possible to the character. The discipline of method acting (short for the "Stanislavski Method" from the name of the Russian theater guru) takes this approach a step further by encouraging actors to apply their own life experiences (and the corresponding emotions) to those felt by their characters, allowing the actor to join with the character in a symbiotic relationship that deepens the connection with the audience. ${ }^{9}$ Method acting encourages the participant to develop deep self-awareness and allows actors to convincingly play a range of different characters in a credible and believable 


\section{American Journal of Pharmaceutical Education 2020; 84 (9) Article 8062.}

manner. ${ }^{10}$ Critical to any approach to acting, regardless of the subject matter or style, are the foundational components of focusing on the audience and understanding the importance of establishing and nurturing productive emotional connections with them. In a larger sense, the idea of performance in general as a directional activity (meaning directed from the performer to the audience) is less accurate than the concept of a relationship being formed between the performer and the audience. ${ }^{11}$

A logical question raised through the comparison of teaching and acting is how can we as faculty members seeking to improve our craft incorporate these lessons from acting without becoming lost in the improvement process itself? I believe the key lies in our basic approach to teaching, embodied in the question, "Where are you when you are teaching?" Actor Patrick Stewart, famous for his roles as Captain Jean-Luc Picard in Star Trek: The Next Generation and Professor X in the X-Men movie series, began his acting career in the United Kingdom as a member of the Royal Shakespeare Company. Even after his stints in those famous movie and television roles, he returned to the stage to act in a production of Samuel Beckett's Waiting for Godot. When discussing his approach to the theater and live acting, Stewart has noted that his focus prior to and during his performance is on the audience member who has never experienced the theater before and to make sure throughout the play that he remains present with the audience and authentic to the emotions felt by the characters. ${ }^{12}$ In essence, Stewart keeps his focus on being and remaining present with the audience so that each attendee can truly engage in a relationship with him through his character and experience the intended emotions along with him.

Analogous to an actor's approach to each performance being the first (and maybe only) one that an audience member will experience, it is critical for us as educators not to lose sight that the learners (our "audience") may only experience one "performance" (or "moment" in acting parlance) of our material. While we can reflect and consider our entire body of work as educators, each learner deserves the opportunity of being "present" with the educator in the same way an actor should be present with the audience during a performance. Understanding this aspect can help us to improve not just our teaching but our personal and professional relationships with others as well.

In discussions with other faculty members, both within and apart from evaluations and performance reviews, there are typically conversations about improvements and changes in the delivery of content over time. These types of iterative changes could include the addition or removal of new or extraneous information, inclusion of new active-learning modalities, or even a complete overhaul of course material, all of which are likely valid and necessary alternations. But I encourage instructors and faculty members to take the opportunity during their normal processes for performance improvement to consider how well they seek out connections with learners during their instructional time and whether they are truly present "in the moment" of learning. Similar to how actors seek connection with the audience, teachers should seek connection with learners and be focused on the overall experience of learning itself rather than solely on the intricacies of the changes made since the last offering of the material or that should be made in the future.

Being reliably in the moment and present with learners are attributes that may seem logical as best practices, but their continued execution can also take practice and repetition to improve just like any skill we work to develop over our careers. As a means of facilitating this practice in my own teaching, I have begun to take a few moments prior to any instructional activity to center myself cognitively and reflect on the notion that learners deserve my full attention and engagement with them, just as I would expect that level of engagement from anyone with whom I am communicating or working. Regardless of the content delivered or modality of instruction, resetting our cognitive focus on making the most out of the relationship formed between instructor and learner can help us provide the best experience for our audience.

\section{REFERENCES}

1. Baruch Y. Role-play teaching: acting in the classroom. Manag Learn. 2006;37(1):43-61.

2. Dawe HA. Teaching: a performing art. $P D K .1984 ; 65(8): 548-552$.

3. Romanelli F, Cain J, McNamara PJ. Should TED Talks be teaching us something? Am J Pharm Educ. 2014;78(6):Article 113. 4. Romanelli F. Are great teachers great storytellers? Am J Pharm Educ. 2016;80(6):Article 93.

5. Griggs $T$. Teaching as acting: considering acting as epistemology and its use in teaching and teacher preparation. Teach Educ $Q$. 2001;28(2):23-37

6. Gregory MW. From Shakespeare on the page to Shakespeare on the stage: what I learned about teaching in acting class. Pedagog. 2006;6(2):309-325.

7. Beijaard D. Teaching as acting: a reconstructive study of an action theoretical approach to research and development in the domain of teaching [dissertation]. Wageningen: Wageningen University \& Research; 1990.

8. Hart R. Act like a teacher: teaching as a performing art [dissertation]. Amherst: University of Massachusetts; 2007. 9. Krasner D. Method acting reconsidered: theory, practice, future. New York, NY: St. Martin's Press; 2000.

10. Morse RA. Commedia dell'Arte as a metaphor for the art of teaching. Phys Teach. 2015;53:392-393. 


\section{American Journal of Pharmaceutical Education 2020; 84 (9) Article 8062.}

11. Özmen KS. Acting and teacher education: the BEING model for identity development. Turk Online J Qual Inq. 2011;2(2):36-49.

12. Cavendish D. Sir Ian McKellen and Patrick Stewart on waiting for Godot. The Telegraph. March 31, 2009. https:// web.archive.org/web/20200817032110/https:/www.telegraph.co.uk/ journalists/dominic-cavendish/5083707/Sir-Ian-McKellen-and-

Patrick-Stewart-on-Waiting-For-Godot.html. Accessed September 1, 2020 . 